\title{
SURGICAL ANATOMY OF THE MAXILLARY NERVE IN THE ZYGOMATIC REGION
}

\author{
ANATOMIA CIRÚRGICA DO NERVO MAXILAR NA REGIÃO ZIGOMÁTICA
}

\author{
Elizandra Paccola MORETTO ${ }^{1}$, Gustavo Henrique de SOUZA SILVA², João Lopes TOLEDO FILHO ${ }^{3}$, \\ Jesus Carlos ANDREO ${ }^{4}$, Ricardo de Lima NAVARRO ${ }^{5}$, João Adolfo Caldas NAVARRO ${ }^{3}$ (in memorian)
}

\author{
1- DDS, graduated at Bauru Dental School, University of São Paulo. \\ 2- DDS, graduated at Bauru Dental School, University of São Paulo. Resident of Oral and Maxillofacial Surgery at Bauru Hospital Association \\ and Brazilian College of Oral and Maxillofacial Surgery and Traumatology. \\ 3- DDS, MSc, PhD, Professor, Discipline of Anatomy, Bauru Dental School, University of São Paulo. \\ 4- DDS, MSc, PhD, Associate Professor, Discipline of Anatomy, Bauru Dental School, University of São Paulo. \\ 5- DDS, MSc graduated at Bauru Dental School, University of São Paulo.
}

Corresponding address: Faculdade de Odontologia de Bauru - Departamento de Ciências Biológicas - Disciplina de Anatomia

Al. Octávio Pinheiro Brisolla, 9-75 - Cep.: 17012-901 - Bauru - SP - e-mail: li_moretto@zipmail.com.br

Received: December 12, 2003 - Modification: May 17, 2004 - Accepted: February 25, 2005

\begin{abstract}
A

natomic knowledge on the zygomatic fossa is of primary importance to improve the regional anesthetic technique of the maxillary nerve. Few reports in the literature have addressed the trajectory of the maxillary nerve and its branches in this region; thus, this study aimed at presenting information about the trajectory of these nerves. Thirty human half-heads of both genders were fixed in 10\% formalin and demineralized in 5\% nitric acid, and the maxillary nerve was dissected since its origin on the pterygopalatine fossa until penetration into the inferior orbital fissure. It was observed that the maxillary nerve sends one to three posterior superior alveolar branches and tuberal descendent branches, which supply the soft tissue structures of the region. The posterior superior alveolar nerves are inferiorly oriented near the maxillary tuberosity, where they penetrate the alveolar canals with the posterior superior alveolar artery and send small nerve branches that continue in an extraosseous trajectory. This study found that nearly $2 / 3$ of the trajectory of the maxillary nerve is located in the zygomatic region, with a short segment $(1 / 3)$ in the pterygopalatine fossa.

Uniterms: Maxillary nerve; Zygomatic region; Trigeminal nerve; Pterygopalatine fossa.
\end{abstract}

\section{RESUMO}

O

conhecimento anátomo-cirúrgico da região zigomática é fundamental para o aprimoramento de técnicas anestésicas tronculares do nervo maxilar. A literatura pouco se refere à trajetória do nervo maxilar e seus ramos nessa região, portanto, o presente estudo tem como objetivo esclarecer o percurso desses nervos. Foram dissecadas ao microscópio cirúrgico MC900 (D.F.Vasconcelos), 30 hemicabeças humanas, de ambos os sexos, que foram previamente formolizadas a $10 \%$ e desmineralizadas em ácido nítrico a 5\%. Observou-se que o nervo maxilar, desde sua origem na fossa pterigopalatina até penetrar na fissura orbital inferior, emite de um a três ramos alveolares superiores posteriores e ramos tuberais descendentes que vão para estruturas moles da região. Os nervos alveolares superiores posteriores, descem adjacentes à tuberosidade da maxila, na qual penetram através dos canais alveolares junto com a artéria homônima e podem emitir filetes nervosos que continuam trajeto extra-ósseo. Contrariando os achados da literatura, com este estudo observou-se que o nervo maxilar apresenta praticamente dois terços de sua trajetória na região zigomática e o restante na fossa pterigopalatina.

Unitermos: Nervo maxilar; Região zigomática; Nervo trigêmeo; Fossa pterigopalatina. 


\section{INTRODUCTION}

The maxillary nerve $\left(\mathrm{V}_{2}\right)$ is the branch of the trigeminal nerve $(V)$ in charge of the sensory and secretomotor innervation of the middle segment of the face. Its connections with autonomic branches at the pterygopalatine fossa provide secretomotor and vasoconstrictor stimulation to lacrimal and mucous glands in general and to the arterial system, respectively ${ }^{1,4,25}$.

Even though many important branches of the maxillary nerve are originated from its segment in the zygomatic region, there are no reports in the literature ${ }^{1,2,4,5,7,10,11,12,17,20,21,23,24,25}$ regarding this trajectory; the same is true for descriptions of regional anesthetic techniques of the $\mathrm{V}_{2}$.

The tuberal region, in its proximity with the pterygomaxillary fissure, corresponding to the anterior limits of the pterygopalatine fossa, is an important anatomic reference to locate the maxillary artery during surgical hemostasis of epistaxis and to avoid injuries to the maxillary nerve and its branches during regional anesthetic procedures $^{5,10,14,19}$.

Knowledge on the maxillary nerve is of primary importance for regional anesthesia in surgeries such as treatment of trauma, orthognathic surgeries of the midface and craniofacial transition sites. During surgical procedures in this anatomic region, the nervous distribution as well as the arterial, venous and lymphatic vascular net must be preserved as much as possible $e^{5,15}$.

The arterial and nerve branches located in the tuberosity, including the maxillary nerve and artery, are found to be maintained by ligament insertions on the rugosities and/or spine of posterior-superior edge of the pterygopalatine fissure, at the anterior-lateral limit of the lateral lamina of the pterygoid process $6,8,9,10,14,16,25$.

The two or three branches of the posterior superior alveolar nerve leave the maxillary nerve before penetrating into the infraorbital canal. Then, they descend in the maxillary tuberosity, in a close relationship with the maxillary artery, finally entering the posterior alveolar canals and reaching the molar roots, where they communicate in an irregular plexus, originating four terminal branches: dental branches, which supply the molar and premolar roots; alveolar branches, to the alveolar periosteum and gingival mucosa; mucous branches, supplying the maxillary sinus mucosa; and bone branches, which supply the maxilla. In their trajectory, these nerves leave some free branches that supply the oral mucosa and gum, descending to the maxillary tuberosity $^{23}$.

Due to the lack of data in the literature regarding the anatomy of the maxillary nerve in the zygomatic region, the aim of this work was to elucidate the trajectory of this nerve under a surgical-anatomic point of view.

\section{MATERIALAND METHODS}

Thirty human adult half-heads (thirteen left halves and seventeen right halves) of different Brazilian individuals of both genders were used. All half-heads were supplied by the laboratory of the Anatomy Department of Bauru Dental School, University of São Paulo. They were fixed in 10\% formalin, demineralized in 5\% nitric acid to facilitate manipulation, and dissected under a MC900 surgical microscope (D. F. Vasconcellos, Brazil) with objective (200mm) and ocular (12.5mm) lenses, under 10x and 16x magnification.

The pterygoid lateral muscle was first removed by macroscopic dissection of the zygomatic region by a lateral access. Thereafter, under the microscope, both vascular and nervous branches at the tuberal region were dissected, exposing the maxillary artery and nerve with their tuberal branches.

The dissection results were recorded in pictures taken with a digital camera (COOLPIX 995, NIKON, U.S.A.). Additionally, drawings based on a standard figure adapted from Sobotta and Becher ${ }^{18}$ (1988) were performed. Written description was performed according to the photographs and sketches.

\section{RESULTS}

In the 30 half-heads studied, it was found that the maxillary nerve, after its emergency in the pterygopalatine fossa through the foramen rotundum, follows an anterior and lateral direction. Finally, it leaves this fossa by the most superior part of the pterygomaxillary fissure, reaching the zygomatic region.

The trajectory of the maxillary nerve in this region is long and curved. It comes from the pterygopalatine fossa in a generally convex pathway to lateral and inferior position, following an anterior direction to the infraorbital canal.

Posterior superior alveolar nerve branches, along with the posterior superior alveolar artery, descend adjacent to the maxillary tuberosity penetrating together into foramina located in this region.

The number of posterior superior alveolar branches that originate from the maxillary nerve in the zygomatic region can vary from one to three. The following patterns were observed in the present study: one branch in 3 cases (10\%), two branches in 21 cases (70\%) and three branches in 6 cases (20\%) (Figure 1).

\section{DISCUSSION}

The maxillary nerve leaves the skull base through the foramen rotundum and reaches the pterygopalatine fossa, where some branches are sent, such as the zygomatic and pterygopalatine nerves, following an anterior direction from medial to lateral positions, emerging in the zygomatic region.

The dissections performed in this work revealed that the maxillary nerve sends some descendent nerves near the tuberosity that supply the soft tissue structures, besides posterior superior alveolar nerves, which are its main and longer branches in this region. 
Maxillary nerve branches descending adjacent to the maxillary tuberosity form a nervous plexus and are associated with maxillary artery branches ${ }^{16,23}$, such as infraorbital, descendent palatine, zygomatico-orbital, posterior superior alveolar and muscular branches of maxillary artery.

In the present work, it was also observed that the posterior superior alveolar nerves have common trajectory with the posterior superior alveolar artery and can be located above or under this artery. Nerves and arteries penetrate together in the tuberosity by the alveolar foramina of maxilla. These nerves can emit branches that continue in an extraosseous trajectory to the soft tissue structures of this region.

In disagreement with some previous reports that state that the posterior superior alveolar nerves originate from the maxillary nerve in the interior of the pterygopalatine fossa $^{1,2,4,7,11,12,17,20,21,23,25}$, this study reveals its origin in the trajectory of the maxillary nerve in the zygomatic region or infratemporal fossa. Other authors mentioned the trajectory of the maxillary nerve in the zygomatic region, asserting that the posterior superior alveolar nerves emerge from the maxillary nerve in this region ${ }^{3,16}$. On the other hand, other

\section{LEFT SIDE}

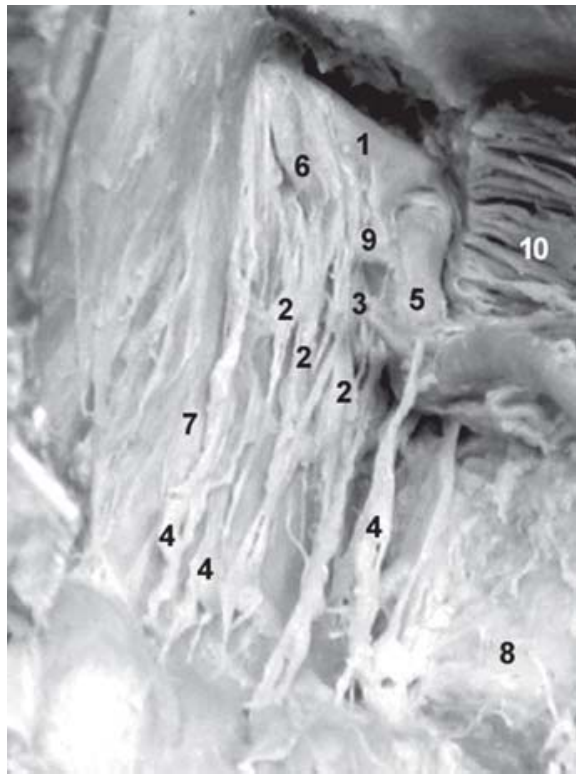

A

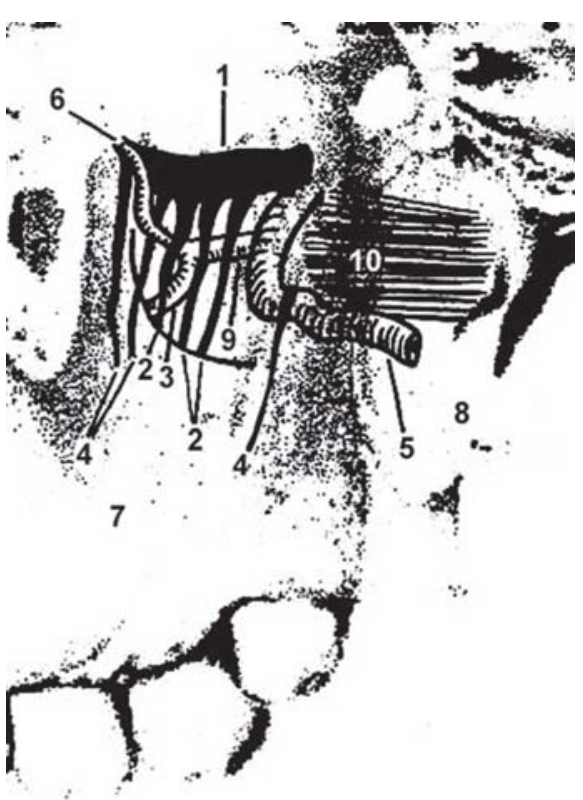

B
RIGTHSIDE

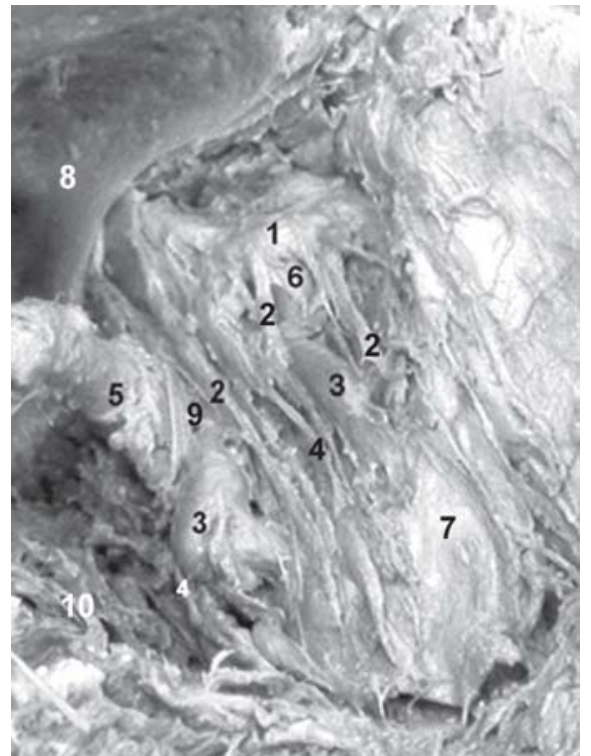

A

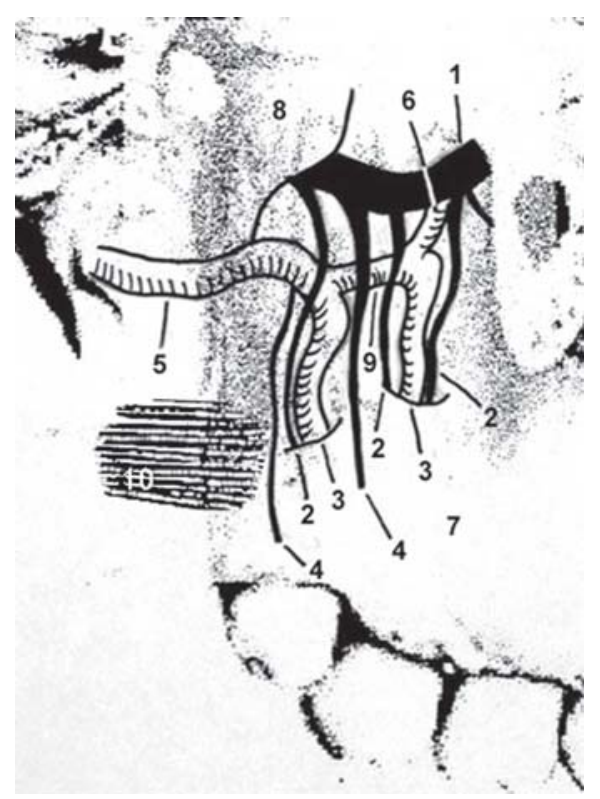

B

FIGURE 1- DISSECTIONS (A) AND SCHEMATIC DRAWINGS (B) OF THE ZYGOMATIC REGION, SHOWING TUBERAL DISTRIBUTION OF THE MAXILLARY NERVE AND ARTERY AND THEIR BRANCHES:

1.Maxillary nerve; 2. Posterior superior alveolar nerve; 3. Posterior superior alveolar artery (ASP); 4. Descendent nervous branches to the zygomatic region; 5. Maxillary artery; 6. Infraorbital artery (IO); 7. Maxillary tuberosity; 8. Lateral lamina of pterygoid process; 9. Arterial trunk (ASP/IO); 10. Lateral pterygoid muscle 
authors have indicated the zygomatic trajectory of the maxillary nerve, yet described that the posterior superior alveolar nerves are originated in the pterygopalatine fossa and then follow to the zygomatic region. Some branches are sent on this trajectory ${ }^{8,17}$.

In this study, it could be observed that, in all cases, nearly $2 / 3$ of the extraosseous trajectory of the maxillary nerve is located in the zygomatic region until its penetration into the infraorbital canal, with a short segment (1/3) in the pterygopalatine fossa.

The maxillary nerve, in its zygomatic trajectory, sent most of its tuberal branches and some nerve branches to soft tissue structures of this region (including temporal and lateral pterygoid muscles). These branches are probably constituted by proprioceptive fibers.

The relationship between the tuberal branches of maxillary nerve and the maxillary artery and its branches is very close and complex. Pterygotuberal ligaments and adipose tissue involve these nerves and arteries.

\section{CONCLUSIONS}

This study revealed that the maxillary nerve sends one to three posterior superior alveolar branches in the zygomatic region. The following was observed from the 30 cases studied: one branch in 3 cases (10\%), two branches in 21 cases (70\%) and three branches in 6 cases (20\%). The maxillary nerve in the zygomatic region sends descendent branches to the soft tissue structures of this region and posterior superior alveolar branches, which descend contiguous to the maxillary tuberosity in variable numbers. Nearly 2/3 of the extraosseous trajectory of the maxillary nerve is located in the zygomatic region. Based on the aforementioned studies, it was concluded that knowledge on the trajectory of the maxillary nerve in the zygomatic region is of primary importance for its location in extra and intraoral anesthetic techniques.

\section{ACKNOWLEDGEMENTS}

The authors would like to express their gratitude to Dr. Carlos Ferreira dos Santos and Juan Carlos Castañeda for the suggestions to this manuscript. E.P.M. was supported by a grant from Fundação de Amparo à Pesquisa do Estado de São Paulo (FAPESP 01/05069-1).

\section{REFERENCES}

1- Baptista BV. Anatomia humana. Rio de Janeiro: Editora Scientifica; 1944. v.1, Tomo 2.

2- Chiarugi G. Instituzioni di anatomia dell'uomo. Milano: Società Editrice Libraria; 1965. v. 5.

3- Figún ME, Garino RR. Anatomia odontológica funcional e aplicada. São Paulo: Panamericana; 1988.
4- Gardner-Gray, O’Rahilly. Anatomia - estudo regional do corpo humano. $2^{\text {nd }}$ ed. Rio de Janeiro: Guanabara-Koogan; 1967.

5- Halgerstan G, Ever H. Introdução à anestesia local odontológica. Barueri: Ed. Manole; 1991.

6- Hamilton WJ. Tratado de anatomia humana. $2^{\text {nd }}$ ed. New York: St Martin's; 1982.

7- Hollinshead WH. Livro texto de anatomia humana. São Paulo: Harper \& Row; 1980.

8- Larrebec WF, Makielski KH. Surgical anatomy of the face. New York: Ed. Raven Press; 1992.

9- Madeira, M.C. Anatomia da face. São Paulo: Ed. Sarvier; 1995.

10- Marzola, C. Anestesiologia. $3^{\text {th }}$ ed. São Paulo: Pancast; 1999.

11- Moore KL. Anatomia orientada para clínica. $2^{\text {nd }}$ ed. Rio de Janeiro: Guanabara Koogan; 1985.

12- Morri's H. Human anatomy. $11^{\text {th }}$ ed. New York: McGraw-Hill; 1942 .

13- Navarro JAC. Cavidade do nariz e seios paranasais. Bauru: Ed. All Dent; 1997.

14- Navarro JAC, Berbert CCV. Contribuição ao estudo do nervo maxilar na fossa pterigopalatina. Rev Bras ORL. 1981; 47:30-8.

15- Navarro JAC, Toledo Filho JL, Costa JL, Gilberto PF. Bases anatômicas para la anestesia del niervo maxilar por la via intrabucal. Rev Odontol Dominicana. 1993;2:17-26.

16- Poirier P, Charpy A , Cunéo B. Abrégé D’Anatomic. Paris: Éditeurs Masson; 1908. Tome 2.

17- Rouvière H. Anatomie humaine descriptiva y topográfica. $3^{\text {th }}$ ed. Paris: Éditeurs Masson; 1932.

18- Sobotta J. Atlas de anatomia humana. $19^{\text {th }}$ ed. Rio de Janeiro: Guanabara-Koogan; 1988. v. 1.

19- Schon-Ybarra MA, Bauer B. Medial portion of m. temporalis and its potencial involvement in facial pain. Clin Anat. 2001;14(1):25-30.

20- Scott JH, Dixon, AD. Anatomy for students of dentistry. $3^{\text {th }}$ ed. Churchill Livingston; 1972.

21- Sicher H, Tandler I. Anatomia para dentistas. São Paulo: Atheneu; 1981.

22- Sinsel NK, Guelincky PJ, Opdebeeck H. The effect of muscle transplantation after unilateral partial facial paralysis on craniofacial growth and development: relatonship between muscle and nerve histomorphometric findings. Plast Reconstr Surg. 2000;105(1):11127.

23- Testut L. Compêndio de anatomia topográfica con aplicaciones medicoquirúrgicas. Rio de Janeiro: Salvat Editora; 1958.

24- Toldt MD. An atlas of human anatomy for students and physicians. New York: The MacMillan Company; 1948. v. 2.

25- Tondury G. Anatomía topográfica y aplicada. Barcelona: Editorial Científico-Médica; 1958. 